\title{
Mesenchymal and trophoblast immunophenotype of multipotent stromal cells from human placenta
}

\author{
V. A. Shablii' ${ }^{1,2}$, M. D. Kuchma ${ }^{1,2}$, V. M. Kyryk ${ }^{3}$, H. M. Svitina ${ }^{2}$, \\ Yu. M. Shablii'², L. L. Lukash ${ }^{1}$, G. S. Lobintseva ${ }^{2}$ \\ ${ }^{1}$ Institute of Molecular Biology and Genetics, NAS of Ukraine \\ 150, Akademika Zabolotnoho Str., Kyiv, Ukraine, 03680 \\ ${ }^{2}$ Institute of Cell Therapy, Ministry of Health of Ukraine \\ 3, Kosmonavta Komarova Ave., Kyiv, Ukraine, 03680 \\ ${ }^{3}$ State Institute of Genetics and Regenerative Medicine, Ukrainian National Academy of Medical Sciences \\ 67, Vyshhorodska Str., Kyiv, Ukraine, 04114 \\ v_shabliy@ukr.net
}

\begin{abstract}
Aim. The investigation of trophoblast markers expression in the mesenchymal stromal cells of placental tissue before and after their isolation and cultivation. Methods. Placental multipotent mesenchymal stromal cells (MMSC) were obtained by culturing the adhesive fraction of cells enzymatically isolated from the placental tissue. The placental derived cells were immunophenotyped by flow cytometry and immunocytoche- mistry. Results. It was shown that the placental MMSC express the trophoblast markers: human chorionic gonadotropin, pan-cytokeratin, epidermal growth factor receptor HER2. MMSC-like populations of CD90 $C D 73^{+} C D 45^{-}$CD $34^{-} C D 14^{-}$-cells and $C D 90^{-} C D 73^{+} C D 45^{\circ} C D 34^{-} C D 14^{-}$-cells are presented in the placental tissue. Conclusions. The placental MMSC simultaneously express mesenchymal and trophoblast markers.
\end{abstract}

Keywords: placenta, chorion, multipotent mesenchymal stromal cells, trophoblast, differentiation.

Introduction. Human placenta contains multipotent mesenchymal stromal cells (MMSC) [1]. It was shown that the placenta derived MMSC had low immunogenicity, high proliferative potential and capacity to differentiate towards the adipogenic, chondrogenic, osteogenic, endothelial, neurogenic and cardiomyogenic lineages [2-4]. The placenta derived MMSC could be represented by both fetal and maternal cells. We have only few data about the features of immunophenotype of different populations of the placental MMSC; immunophenotype and ontogeny of the fetal placental MMSC are almost completely unknown.

In some papers authors described similarity of the placenta-derived MMSC with pericytes $[5,6]$ but on the other hand the placental MMSC expressed a range of trophoblast markers. Thus we consider that the hypothesis about perivascular origin of the placenta-derived MMSC [6] is not enough proved.

(c) Institute of Molecular Biology and Genetics, NAS of Ukraine, 2014
Furthermore a lot of papers were focused on studying MMSC derived from the placental tissue on an early stage of human development (the first and second trimesters of gestation). Together with a variety of cell isolation methods there is also complicated analysis of ontogeny of the placental MMSC $[4,6,7]$.

Materials and methods. Isolation and culture of placental MMSCs. Placentas ( $n=7$; clinically normal pregnancies or caesarean section) were collected after obtaining written informed consent from the 23-36-year old donors at 39-41 weak of gestation at the Kyiv city maternity hospital N 3 .

The isolation and culturing of placental cells were performed as described previously [8]. Placental tissue was digested in DMEM with $0.1 \%$ collagenase I ( $«$ Serva», Germany) and 0.6 unit/ml dispase I («Gibco», Germany). Harvested cells were washed and seeded into DMEM («Sigma», USA) with $15 \%$ FBS («Gibco»), $2 \mathrm{mM}$ L-glutamin, $5 \mathrm{mM}$ HEPES («Biomedicals», 
USA), $100 \mathrm{unit} / \mathrm{ml}$ penicillin, $50 \mu \mathrm{g} / \mathrm{ml}$ streptomycin. Cells were cultured in the cell culture flask with adhesive surface in density $(80-200) \cdot 10^{3}$ cells $/ \mathrm{cm}^{2}$ at $37^{\circ} \mathrm{C}$ in humidified $5 \% \mathrm{CO}_{2}$ atmosphere. Culture medium was changed twice a week. After MMSC reaching 80 $90 \%$ of confluence, the cells were detached with $0.05 \%$ trypsin with $0.02 \%$ EDTA («Biochrom», Germany), washed, counted and passaged at inoculation density of $(4-5) \cdot 10^{3} / \mathrm{cm}^{2}$.

Flow cytometry. The freshly isolated MMSC were washed with cold Cell Wash buffer («Becton Dickinson», USA), and incubated for $30 \mathrm{~min}$ at $4{ }^{\circ} \mathrm{C}$ with fluorochrome-conjugated monoclonal antibodies at appropriate dilution («Becton Dickinson») $0.5 \mu \mathrm{g}$ per $10^{6}$ cells: anti-CD34 APC, anti-CD90 FITC, anti-CD45 APC-Cy7, anti-CD73 PE, anti-CD14 Pacific Blue. Unbounded primary antibodies were washed away with Cell Wash buffer. The samples were analyzed using BD FACSAria («Becton Dickinson») with software BD FACSDiva 6.1. Each sample was analyzed for two parameters of scattering (FSC/SSC) and five parameters of fluorescence, using unstained, single stained and fluorescence minus one (FMO) controls.

Immunocytochemistry. Immunocytochemistry was performed as described earlier [8]. MMSC were grown in 4-well culture dish with surface area $1.9 \mathrm{~cm}^{2}$ (Nun$\operatorname{clon}^{\mathrm{TM}} \Delta$ Surface). MMSC were fixed and permeabilized in acetone/ methanol solution $(\mathrm{w} / \mathrm{w} 1: 1)$ at $-20{ }^{\circ} \mathrm{C}$ for $40 \mathrm{~min}$. The endogen peroxidase activity was inhibited by incubation with $0.3 \% \mathrm{H}_{2} \mathrm{O}_{2}$ for 5 min. Unspecific binding of antibodies was blocked with $0.1 \mathrm{M}$ PBS with $0.5 \%$ BSA. Detection of cytokeratins AE1/ AE3, epidermal growth factor receptor type 2 (HER2), cytokeratin 7 (CK7), chorionic gonadotropin (CG) and vimentin (Vim) was performed with the next primary antibodies: mouse anti-cytokeratin AE1/AE3 («Dako», Denmark), rabbit anti-HER2 («Dako»), rabbit anti-cytokeratin 7 («Novus Biological», USA), mouse anti-cytokeratin 7 («Dako»), rabbit anti-hCG («Dako»), mouse anti-vimentin («Dako»).

Visualization of specific binding was also performed using Mouse/Rabbit Poly Vue HRP/DAB Detection System («DBS», USA).

Double staining for CK7 and vimentin as well as CK7 and CD90 was performed as described earlier [9]. Secondary antibodies were donkey anti rabbit-Alexa 555
(«Invitrogen», Germany) and goat anti mouse-Alexa 488 («Invitrogen»).

Statistical analysis. Data are discribed as mean value \pm s. e. $m$ (standard error) or confidential interval. The statistical differences between groups were assessed by Mann-Whitney $U$-test. The results were considered statistically significant at $\mathrm{P}$ value $\leq 0.05$.

Results and discussion. The colonies of MMSC cells emerged on 8-12 days of culturing and reached a confluence on the $16^{\text {th }}$ day. In our previous publication we have shown that the placental MMSC were of fetal origin, had $\mathrm{CD} 90^{+} \mathrm{CD} 73^{+} \mathrm{CD} 105^{+} \mathrm{CD} 34^{-} \mathrm{CD} 45^{-} \mathrm{CD} 133^{-}$ CD14-immunophenotype and might differentiate in adipocytes, osteocytes and chondrocytes [8].

Immucytochemical analysis showed that the placental MMSC were positive for the trophoblast markers: cytokeratins AE1/AE3 (Fig. 1, A), HER2 (Fig. 1, $B$ ) and $\mathrm{CG}$ (Fig. 1, $C$ ) during six passages. The placental MM $\mathrm{SC}$ expressed the trophoblast marker $\mathrm{CG}$ and marker of mesenchymal cells Vim simultaneously (Fig. 1, C). The CK7 positive cells also expressed CG (Fig. 1, E) that proves their extravillous trophoblast ontogeny (EVT). Notably, the $\mathrm{CK}^{+}$-cells expressed the stem cells marker CD90 (Fig. 1, F).

The population of double positive cells for Vim and CK7 (Fig. 1, D) significantly decreased from $37.6 \%$ (26.6-49.4\%, ) at the first passage to $13.4 \%(2.5-31.1 \%)$ at the third passage $(n=6 ; \mathrm{p}<0.05)$.

HER2 was exclusively expressed on non-mesenchymal cells such as the syncytiotrophoblast and extravillous trophoblast (EVT) in the placental tissue but it was also detected on the bone marrow derived MMSC [10].

Furthermore, the expression of cytokeratin AE1/ AE3 and CG by the placental MMSC during six passages may suggest their relationship with progenitors of trophoblast. CG was also detected in placental stromal cells of fetal origin in vitro $[11,12]$.

FACS analysis of some placental MMSC lines showed bi-modal pattern of the expression of CD90 and correspondingly the presence of both $\mathrm{CD} 90^{+}$and CD90- populations of cells (Fig. 2).

We showed that placental tissue in situ contain both population of MMSC-like cells (Fig. 3) with immunophenotype $\mathrm{CD} 90^{+} \mathrm{CD} 73^{+} \mathrm{CD} 45^{-} \mathrm{CD} 34^{-} \mathrm{CD} 14^{-}(0,22 \pm$ $\pm 0,14 \%, n=4)$ and $\mathrm{CD} 90^{-} \mathrm{CD} 73^{+} \mathrm{CD} 45^{-} \mathrm{CD} 34^{-} \mathrm{CD} 14$ $(3,61 \pm 2,45 \%, n=4)$. Placental stromal mesenchymal 

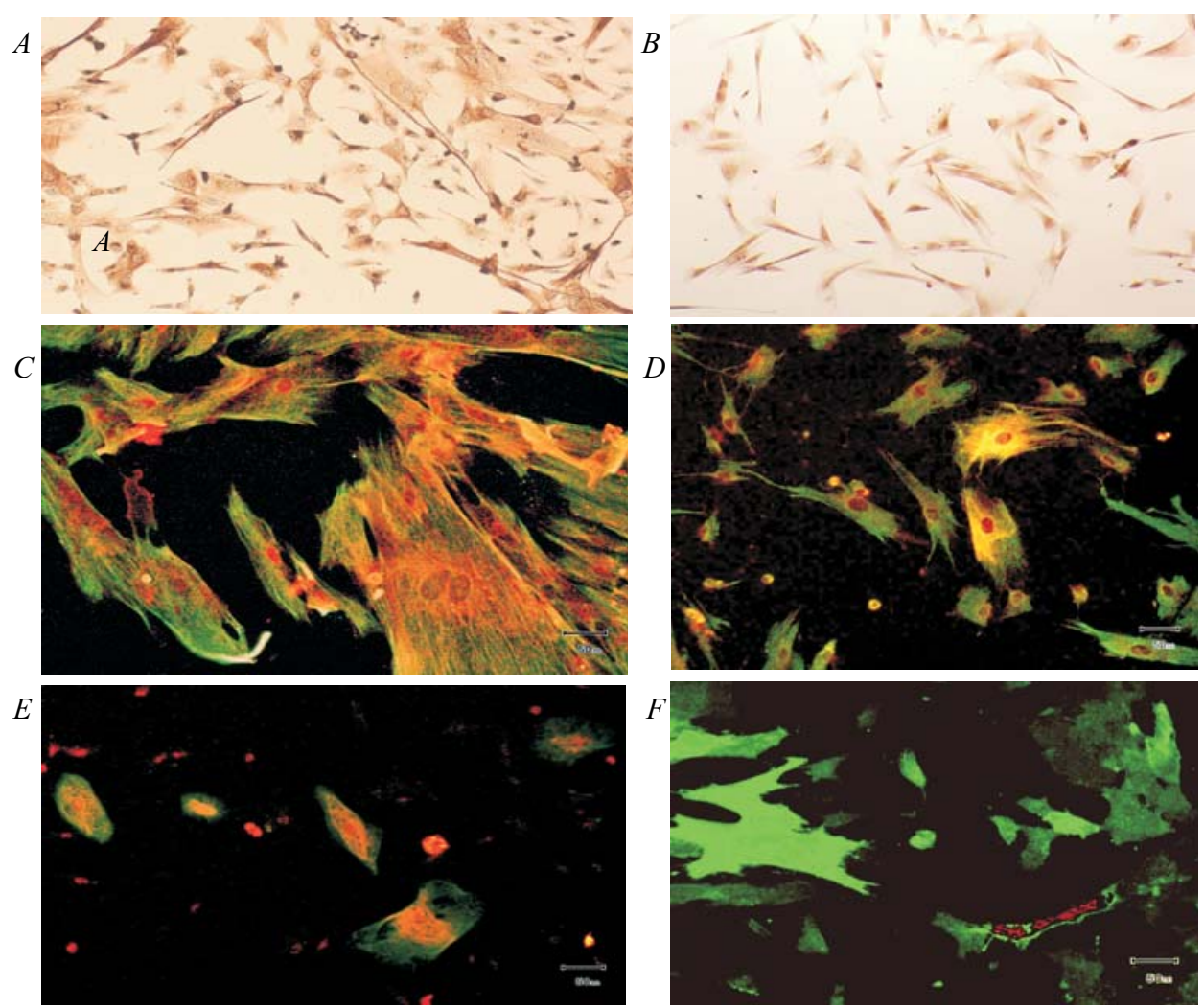

Fig. 1. Immunocytochemical staining of stromal cells culture of placenta: detection of cytokeratin AE1/AE3 $(A)$ and HER2 $(B)$; immunoperoxidase cytochemical analysis; brown positive cells, light microscopy, $\times 100$; $C$ - detection of CG (yellow staining) and Vim (green staining); $D-$ detection of Vim (green staining) and CK7 (yellow); $E$ - detection of CG (yellow) and CK7 (green staining); $F$ - detection of CK7 (red) and CD90 (green); fluorescence microscopy
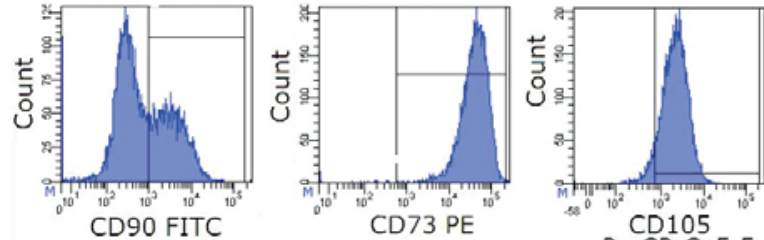

PerCP-Cy 5.5
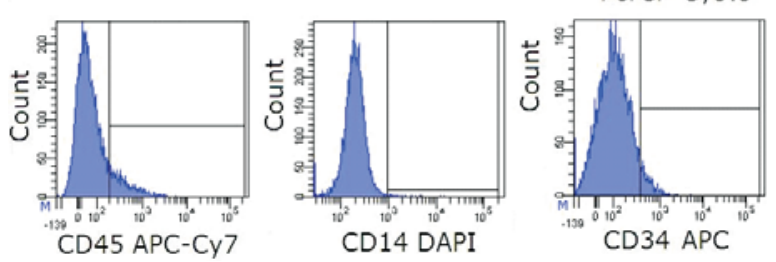

Fig. 2. Histograms of placental MMSC antigen profile: blue - level of expression of CD90, CD73, CD105, CD34, CD14, CD45; (BD FACS Diva 6.1.2 software)

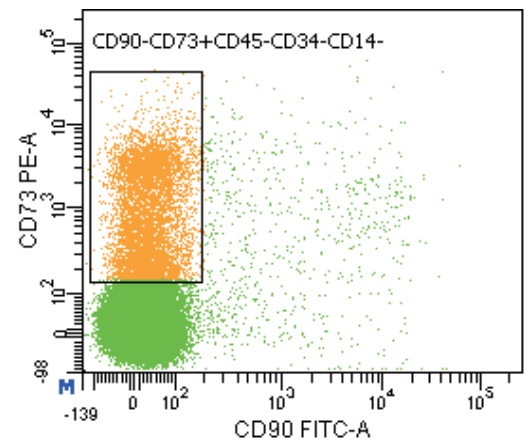

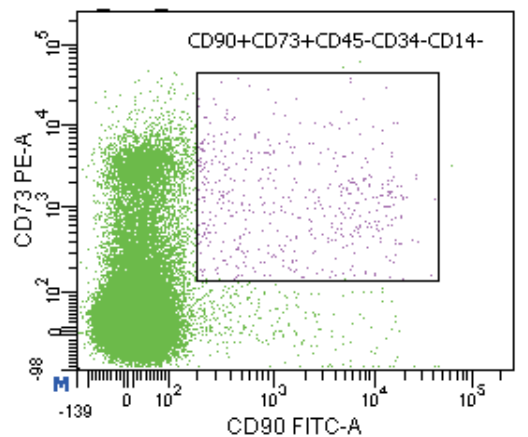

Fig. 3. Two-dimensional dot-plot histograms of surface markers expression $\mathrm{CD}$ 90, CD73, CD105, CD34, CD14, CD45 on freshly isolated cells by fermentation of placental tissue: $A$ - population of cells with immunophenotype of $\mathrm{CD} 90^{-\mathrm{CD}}$ $73^{+} \mathrm{CD} 45^{-} \mathrm{CD} 34^{-} \mathrm{CD} 14^{-} ; B$ - population of cells with immunophenotype of $\mathrm{CD}$ $90^{+} \mathrm{CD} 73^{+} \mathrm{CD} 45^{-} \mathrm{CD} 34^{-} \mathrm{CD} 14^{-}$; (BD FACS Diva 6.1.2 software) 
their relation to some type of EVT progenitors. Thus, differences between mesenchymal stromal and trophoblast placental cells in vitro remains insufficiently clear.

Conclusions. It has been shown that the placental MMSC express the trophoblast markers such as CG, CK7, cytokeratin AE1/AE3, HER2. The placental cells in situ have MMSC-like populations with both immunophenotypes $\mathrm{CD} 90^{+} \mathrm{CD} 73^{+} \mathrm{CD} 45^{-} \mathrm{CD} 34^{-} \mathrm{CD} 14^{-}$and $\mathrm{CD} 90^{-} \mathrm{CD} 73^{+} \mathrm{CD} 45^{-} \mathrm{CD} 34^{-} \mathrm{CD} 14^{-}$.

Мезенхімально-трофобластний імунофенотип

мультипотентних стромальних клітин плаценти людини

В. А. Шаблій, М. Д. Кучма, В. М. Кирик , Г. М. Світіна,

Ю. М. Шаблій, Л. Л. Лукаш, Г. С. Лобинцева

Резюме

Мета. Дослідити експресію маркерів трофобласта в мультипотентних стромальних клітинах у тканині плаченти та за умов їхнього культивування. Методи. Мультипотентні мезенхімальні стромальні клітини (ММСК) отримували культивуванням адгезивної фракиії суспензії клітин тканини плаценти, імунофенотипування клітин проводили за допомогою проточної цитофлуорометрії та імуноцитохімії. Результати. Показано, що ММСК плаценти експресують маркери трофобласта: хоріонічний гонадотропін, иитокератини AE1/AE3, рецептор епідермального фактора росту HER2. У тканині плаценти присутні подібні за імунофенотипом до МMCK популяиії $C D 90^{+} C D 73^{+} C D 45^{-} C D 34^{-} C D 14^{-}$клітин і $C D 90^{-} \mathrm{CD} 73^{+} \mathrm{CD} 45^{-} \mathrm{CD} 34^{-} \mathrm{CD} 14^{-}$-клітин. Висновки. Плацентарні ММСК одночасно експресують мезенхімальні та трофобластні маркери.

Ключові слова: плачента, хоріон, мультипотентні мезенхімальні стромальні клітини, трофобласт, диферениіювання.

Мезенхимально-трофобластный иммунофенотип мультипотентных стромальных клеток плаценты человека

В. А. Шаблий, М. Д. Кучма, В. М. Кирик, А. Н. Свитина, Ю. М. Шаблий, Л. Л. Лукаш, Г. С. Лобинцева

Резюме

Цель. Исследовать экспрессию маркеров трофобласта в мультипотентных стромальных клетках в ткани плаценты и в условиях их культивирования. Методы. Мультипотентные мезенхимальные стромальные клетки (ММСК) получали культивированием адгезивной фракиии суспензии клеток ткани плаченты, иммунофенотипирование клеток проводили с помощью проточной циитофлуорометрии и иммуноцитохимии. Результаты. Показано, что ММСК плаценты экспрессируют маркеры трофобласта: хорионический гонадотропин, цитокератины AE1/AE3, рецептор эпидермального фактора роста HER2. В ткани плаченты присутствуют похожие по иммунофенотипу на МMCK популячии $C D$ $90^{+} \mathrm{CD} 73^{+} \mathrm{CD} 45^{-} \mathrm{CD} 34^{-} \mathrm{CD} 14^{-}$-клеток и $C D 90^{-} \mathrm{CD} 73^{+} \mathrm{CD} 45^{-} \mathrm{CD} 34$ CD14 -клеток. Выводы. Плаиентарные ММСК одновременно экспрессируют мезенхимальные и трофобластные маркеры.

Ключевые слова: плацента, хорион, мультипотентные мезенхимальные стромальные клетки, трофобласт, дифференцировка.

\section{REFERENCES}

1. Abdulrazzak H, Moschidou D, Jones G, Guillot PV. Biological characteristics of stem cells from foetal, cord blood and extraembryonic tissues. J R Soc Interface. 2010; 7(Suppl 6): S689-706

2. Li C, Zhang $W$, Jiang $X$, Mao $N$. Human-placenta-derived mesenchymal stem cells inhibit proliferation and function of allogeneic immune cells. Cell Tissue Res. 2007; 330(3):437-46.

3. Pojda Z, Machaj EK, Oldak T, Gajkowska A, Jastrzewska M. Nonhematopoietic stem cells of fetal origin - how much of today's enthusiasm will pass the time test? Folia Histochem Cytobiol. 2005; 43(4):209-12.

4. Jones GN, Moschidou D, Puga-Iglesias TI, Kuleszewicz K, Vanleene M, Shefelbine SJ, Bou-Gharios G, Fisk NM, David AL, De Coppi $P$, Guillot $P V$. Ontological differences in first compared to third trimester human fetal placental chorionic stem cells. PLoS One. 2012; 7(9):e43395.

5. Castrechini NM, Murthi P, Gude NM, Erwich JJ, Gronthos S, Zannettino A, Brennecke SP, Kalionis B. Mesenchymal stem cells in human placental chorionic villi reside in a vascular Niche. Placenta. 2010; 31(3):203-12.

6. Robin C, Bollerot K, Mendes S, Haak E, Crisan M, Cerisoli F, Lauw I, Kaimakis P, Jorna R, Vermeulen M, Kayser M, van der Linden R, Imanirad P, Verstegen M, Nawaz-Yousaf H, Papazian $N$, Steegers E, Cupedo T, Dzierzak E. Human placenta is a potent hematopoietic niche containing hematopoietic stem and progenitor cells throughout development. Cell Stem Cell. 2009; 5(4): 385-95.

7. von Koskull H, Virtanen I. Induction of cytokeratin expression in human mesenchymal cells. J Cell Physiol. 1987; 133(2):321-9.

8. Shablii V, Kuchma M, Kyryk V, Onishchenko G, Areshkov P, Skrypnyk N, Lukash L, Lobyntseva G. Characteristics of placental multipotent mesenchymal stromal stem cells. Cell Transplantation and Tissue Engineering. 2013; VIII(4):55-61.

9. Shablii VA, Kuchma MD, Kyryk VM, Onishchenko GM, Tsupykov OM, Klymenko PP, Areshkov PA, Kuchuk OV, Lukash LL, Lobyntseva GS. Phenotype and migration potential of multipotent mesenchymal stromal cells from native and cryopreserved human placenta. Biotechnology (Ukr). 2012; 5(5):34-44.

10. Buhring HJ, Battula VL, Treml S, Schewe B, Kanz L, Vogel W. Novel markers for the prospective isolation of human MSC. Ann N Y Acad Sci. 2007; 1106:262-71.

11. Tskitishvili E, Sharentuya N, Temma-Asano K, Mimura K, Kinugasa-Taniguchi Y, Kanagawa T, Fukuda H, Kimura T, Tomimatsu T, Shimoya K. Oxidative stress-induced S100B protein from placenta and amnion affects soluble Endoglin release from endothelial cells. Mol Hum Reprod. 2010; 16(3):188-99.

12. Bukovsky A, Cekanova M, Caudle MR, Wimalasena J, Foster JS, Henley DC, Elder RF. Expression and localization of estrogen receptor-alpha protein in normal and abnormal term placentae and stimulation of trophoblast differentiation by estradiol. Reprod Biol Endocrinol. 2003; 1:13.

13. King A, Thomas L, Bischof P. Cell culture models of trophoblast II: trophoblast cell lines - a workshop report. Placenta. 2000; 21 (Suppl A):S113-9.

Received 15.09.13 